\title{
A NATUREZA HISTÓRICA DO HUMANO
}

\section{THE HISTORICAL NATURE OF THE HUMAN BEING}

\section{LA NATURALEZA HISTÓRICA DEL HUMANO}

\section{RESUMO:}

Carlos Alvarez Maia ${ }^{1}$

Este trabalho trata da condição humana segundo o olhar histórico. A proposta clássica de ser humano oriunda do substancialismo racional-iluminista conflita com o pensamento histórico, tanto na instância filogenética, de sua hominização antropológica que constrói a espécie, como também na ontogenética, de sua humanização dada pela historicidade vivencial de cada indivíduo biológico em seu devir humano. Penso o humano como um ser constituído na instância simbólica da linguagem em sua prática interativa entre natureza e sociedade.

Palavras-chave: Constituição histórica do humano; A linguagem e o ser humano; História e linguagem.

\section{ABSTRACT:}

This work deals with the human condition under a historical perspective. The classical proposal of human being originated from the illuminist - rational substantialism conflicts with the historical thought, both in the phylogenetic instance of its anthropologic hominization which builds up the species, and in the ontogenetics of its humanization given by the living historicity of each biological individual in his/her human cycle. I think of the human being as an entity made in the symbolic instance of the language in his/her interactive practice between nature and society.

Keywords: Historical constitution of the human being; The language and the human being; History and language.

\section{RESUMEN:}

Este trabajo trata de la condición humana según la mirada histórica. La propuesta clásica de lo que sea el ser humano, oriunda del sustancialismo racional iluminista, contrapone con el pensamiento histórico, tanto en la instancia filogenética, de su hominización antropológica que construye la especie, como también en la ontogenética, de su humanización dada por la historicidad vivencial de cada individuo biológico en su transformación humana. Pienso el humano como un ser constituido en la instancia simbólica del lenguaje en su práctica interactiva entre la naturaleza $y$ la sociedad. Palabras-clave: Constitución histórica del humano; El lenguaje y los seres humanos; La historia y el lenguaje.

\footnotetext{
${ }^{1}$ Doutor em História, professor adjunto do Departamento de História da Universidade Estadual do Rio de Janeiro (UERJ), coordenador do Laboratório de Estudos Históricos da Ciência, LEHC-UERJ. E-mail: alvarez@iis.com.br
} 


\section{INTRODUÇÃO}

Como estabelecer qual é a essência do humano? O que é o humano?

Há dois olhares básicos para apreender o conceito de "humano": o individual e o coletivo. De um lado temos a compreensão do humano que tenta responder às questões considerando suas características naturais, as qualidades intrínsecas de cada ser, do corpo e mente de cada indivíduo - típico na: biologia, neurociências, psicologia cognitiva etc. - e de outro encontramos as ciências sociais que privilegiam a análise sobre os indivíduos considerando seus modos de existência, suas práticas efetivas em sociedade. Neste caso, as qualidades que tipificam o humano são extraídas de sua forma de vida coletiva.

\section{INTRODUÇÃO AO HUMANO EM HISTÓRIA}

Aqui me alinho com a perspectiva sócio-antropológica para o entendimento do humano. É um ponto de partida fornecido por um dado empírico, somente se conhecem indivíduos humanos que vivam coletivamente. $O$ indivíduo humano encontra-se enlaçado com outros indivíduos e é a forma desse enlace que o caracteriza. A humanidade do homem somente ocorre em seu viver societário, não conhecemos exceção. Essa humanidade de cada homem é uma propriedade relacional. Não há humano isolado. Isso desloca o objeto de pesquisa, o alvo a ser investigado. Em vez de pensar em humanidade como uma substância inerente ao ser individual, penso em humanidade como uma qualidade contingencial dada pela configuração abstrata de seus enlaces coletivos. A resposta para a questão do homem não se esgota em algo material encontrado em seu corpo, ou mente; será mais próprio investigar a imaterialidade de suas relações concretas que the dão especificidade. Os indivíduos humanos dependem dessas relações, eles são indivíduos diferentes entre si dependendo do tipo de relações sociais que estabeleçam. Um aborígene australiano é um ser existencialmente diverso de qualquer indivíduo que viva em uma grande metrópole contemporânea, apesar de ambos possuírem as mesmas características biofísicas. O que os difere encontra-se no tipo de malha societária em que cada um vive e não na materialidade de seus corpos.

R. Inter. Interdisc. INTERthesis, Florianópolis, v.6, n.1, p. 15-47, jan./jul. 2009 
Considero ainda que a distância fundamental dos humanos para os demais animais não é a sua criatividade na produção de ferramentas nem a ocorrência de processos comunicacionais dados por aquilo que genericamente chamamos linguagem. Esses fatos não nos dão um diferencial absoluto em relação aos outros animais. Ferramentas e comunicação ocorrem, ainda que em graus diferentes, em várias espécies. O que distingue os humanos, o que lhes é único, é o fato de que este animal humano ingressou em novo tipo de abstração organizacional, a sociedade. Mas ele é um ser social bem específico, a sua sociabilidade é distinta e difere do modo de organização coletiva das formigas ou abelhas, ou de uma matilha. ${ }^{2}$ Ele é um ser histórico, as sociedades humanas são históricas. São sociedades que sofrem profundas mudanças segundo o evolver dos tempos históricos. É um ser que depende de sua diacronia, o ser humano da época de Aristóteles e o ser humano de nossa pós-modernidade são radicalmente diferentes. Sentem o mundo de maneiras bastante diversas, vêem mundos diferentes. Possuem formas de vida wittgensteinianas bem distintas. $E$ isto é único no reino animal.

Minha proposta considera que aquilo que diferencia o humano dos demais animais seja sua "natureza" histórica. A "natureza" histórica do humano impede que se obtenha uma qualidade estável e permanente do humano simplesmente porque a humanidade do homem está em constante mudança, ele próprio é um ser em contínua transformação. Capturar aquilo que dá identidade e especificidade ao humano seria capturar aquilo que o faz um ser histórico. O humano é um devir contínuo. Nos últimos 30 mil anos o animal humano surgiu e é razoavelmente o mesmo do ponto de vista biológico porém a mutação ocorrida em sua forma de vida é notável. $\mathrm{O}$ antropóide primitivo é irreconhecível ante o ser contemporâneo. Ainda que ambos tenham o mesmo substrato físico.

Ainda hoje é usual nas áreas ligadas às ciências cognitivas buscar nos elementos materiais de sua constituição psicofísica as explicações para a genialidade e a supremacia humanas dadas pelas qualidades neuronais de um indivíduo. Há anos discute-se o "cérebro de Einstein". ${ }^{3}$

\footnotetext{
${ }^{2} \mathrm{O}$ fundamento das relações societárias humanas é dado pelas relações de poder como analisado por Hegel em sua Fenomenologia do espírito.

${ }^{3}$ Há farto noticiário sobre o assunto que circula há mais de 40 anos em alguns setores acadêmicos. Tenta-se descobrir o que o cérebro de Einstein, recolhido em sua autópsia, teria de notável. Ver, por exemplo, a Folha de São Paulo de 13/01/2005 em http://www1.folha.uol.com.br/folha/ciencia/ult306u12832.shtml
} 
Penso que sejam as propriedades do devir histórico que forneçam as mais consistentes explicações para a excepcionalidade humana. Pedra lascada, polida, era dos metais foram etapas articuladas e necessárias para criarem as condições de possibilidade para o desenvolvimento de inovadoras formas de vida individualcoletiva. Assim, somente quando a sociedade organizou-se em torno da escrita é que foi possível eclodirem pensamentos e práticas decorrentes de níveis de abstração mais profundos. A escrita emerge e torna possível a existência de um Platão, de um "alvorecer" grego. Não antes, um ser com as qualidades de Platão hipoteticamente nascido durante a era da pedra polida não poderia produzir o que o "nosso" Platão produziu. As qualidades psicofísicas individuais são insuficientes para explicarem as transformações históricas.

Recorde-se que brilhantes geômetras gregos tentavam resolver problemas que testavam o limite da inteligência e criatividade humanas ao investigarem soluções para desafios como o dos "três problemas clássicos da Antiguidade": da quadratura do círculo, da trissecção do ângulo ou da duplicação do cubo. ${ }^{4} \mathrm{~A}$ habilidade dos gregos foi comprovadamente eficaz para equacionar ou propor vários desses desafios porém se acompanharmos o evolver histórico teremos um outro entendimento da "genialidade" humana. Como um exemplo simples da "genialidade" dada pelas condições históricas vejamos o exercício escolar: encontrar o quadrado cuja área é menor em 20 unidades que a de um retângulo que tenha um dos lados igual ao do quadrado e que o outro seja igual a 9. Na geometria de Euclides esse problema tem solução porém exige a presença de um expert. Entretanto, hoje, qualquer estudante de primeiro ciclo sabe resolver trivialmente tal desafio como uma solução da equação do segundo grau, $x^{2}-9 x+20=0$, cujas raízes são 4 e 5 . Isto é, uma criança contemporânea é capaz de responder a essa questão e de ir ainda muito mais além. Ela sabe demonstrar que há duas soluções para esse problema grego - o quadrado de lado 4 e o quadrado de lado 5 - e mais, que somente há essas duas soluções e não há outras mais.

Ora, certamente os gregos foram "geniais" mas a grande e genérica "genialidade" encontra-se no processo histórico que permite que simples crianças resolvam hoje o que somente era possível de ser encontrado por geômetras

\footnotetext{
${ }^{4}$ Ver qualquer manual de história da matemática, por exemplo, Carl B. Boyer. História da Matemática. São Paulo: Edgar Bluncher Ltda, 1996. Em termos algébricos, por exemplo, a quadratura do círculo é trivial. Seja Sc a área do círculo de raio $\mathrm{R}$ e Sq a área do quadrado de lado $\mathrm{L}$, então para $\mathrm{Sc}=\mathrm{Sq}$ é necessário que $\pi R^{2}=L^{2}$, logo $L=R \sqrt{ } \pi$.
}

R. Inter. Interdisc. INTERthesis, Florianópolis, v.6, n.1, p. 15-47, jan./jul. 2009 
excepcionais. A diferença entre o geômetra grego e o estudante atual encontra-se na historicidade de ambos. As condições históricas de cada ser the fornecem as suas condições de possibilidades para atuar no mundo, para vencer os problemas de sua prática vivencial, são possibilidades de seu tempo histórico. Há, desde a instalação da álgebra, um outro grau de abstração societariamente construído que transforma complexos problemas geométricos e os decodifica em soluções algébricas infantis. São soluções encontradas por qualquer criança hoje, da Namíbia a New York. E isto me parece "genial".

O processo histórico fornece os índices para a "genialidade" humana e eleva a nossa espécie a um patamar de distinção ante os outros animais, nos retira de um simples estado de natureza comum e configura estados outros, mas de uma natureza abstrata, natureza construída. O próprio homem constrói sua natureza.

Cada demonstração de genialidade da racionalidade de indivíduos excepcionais está situada historicamente. Se nos restringíssemos à visão individualista desse processo seríamos levados a compreender o progresso humano como formado por saltos dados por indivíduos excepcionais. Dependeríamos totalmente da inesperada ocorrência desses raros indivíduos para explicarmos o devir societário. Nesse caso, a diferença entre os humanos e os animais seria dada pela condição de, na espécie humana, surgirem eventualmente alguns indivíduos com qualidades supremas e diferenciadas. Esse modelo de descrição histórica já teve a sua época, grassou na história das idéias. É o modelo que descreve o avatar humano como uma lenda de "gigantes sobre ombros de outros gigantes". 5

Esse é um modelo para um tipo de história que desvenda simplesmente os indivíduos como causas para esse modo de evolver - evidente que haja necessidade da ação individual para que as sociedades se transformem porém esta perspectiva não captura o ser histórico. É certo que cada solução solicitada por um problema em determinado tempo histórico será encontrada pelos indivíduos mais habilidosos daquele tempo. Isto é banal e nada explica. Está em Darwin. Qualquer empresário sabe disto, sabe que deve contar com uma equipe competente de especialistas para resolver os problemas que a empresa vai enfrentar. Que os mais

\footnotetext{
${ }^{5}$ Trata-se de um aforismo atribuído a Newton que declarava ter visto mais longe pois estava em "ombros de gigantes", dos seus antecessores, dentre eles o célebre Galileo. Stephen Hawking, um conhecido físico contemporâneo escreveu um livro de divulgação com esse título: "Os gênios da ciência: sobre os ombros dos gigantes". Em história das idéias é usual esta referência mostrando o evolver da ciência como um progresso dado pela genialidade de indivíduos que se sucedem, "gigantes sobre ombros de gigantes".
}

R. Inter. Interdisc. INTERthesis, Florianópolis, v.6, n.1, p. 15-47, jan./jul. 2009 
competentes devem ser, em geral, os vencedores do processo é uma constatação que nenhum administrador empresarial duvida. A genialidade individual, seja lá o que for isto, nada explica sobre a lógica mais ampla do processo de transformação social, afinal, sempre o vencedor darwinista será o mais apto para resolver os desafios de um tempo histórico.

Com a "história de gigantes sobre ombros de outros" simplesmente se arranhou a superfície do conceito de história. Revelou-se que história é algo que ocorre na diacronia, no passar dos tempos. Mas há muito mais abstração envolvida no conceito. Não há como pensar em história sem pensar na contaminação societária de uns indivíduos por outros, em seu existir coetâneo. As relações que os indivíduos estabelecem entre si é que aprisionam, ou expandem, as possibilidades daquele existir. $\mathrm{O}$ indivíduo possui uma forma de vida contaminada pelas demais formas de vida de seu tempo. São relações sincrônicas. O que garante que cada indivíduo entre no devir histórico é sua vida coletiva, são as relações sincrônicas que ele estabelece. Que fale o mesmo idioma, partilhe dos mesmos valores dos demais. O mistério da historicidade humana encontra-se nesse amplo contágio horizontal entre os indivíduos de uma mesma época e lugar. Este contágio sincrônico será recebido pelos habitantes do futuro, em um outro "contágio", verticalizado, de segunda ordem, diacrônico. Uma herança. E uma geração poderá passar à seguinte suas experiências conquistadas por suas formas de vida. Desde que sincronicamente haja contaminação de uns pelos outros. Isto é básico para a história: a sincronia articulada com a diacronia. E a história se faz no cruzamento de ambas.

O indivíduo isolado - como o mito de Robinson Crusoé dos séculos XVIII e $\mathrm{XIX}^{6}$ - nada conquista de histórico, não há pares, não há contágio societário, não há sincronia, não há história. Nada herda e nada transmite. O indivíduo fora das relações sincrônicas com outros indivíduos nada é, está fora da história e perdeu seu diferencial humano. Fica reduzido à sua biologia e não conquista sua humanidade.

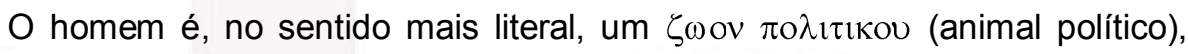
não somente um animal social, mas sim um animal que só pode

\footnotetext{
${ }^{6}$ Marx foi um feroz crítico desse modelo centrado na individualidade dos atores, isolados e extraídos do tecido societário. A isso ele denominava de "robinsonadas" e reagia aos economistas clássicos "o caçador e o pescador individuais e isolados, com que começam Smith e Ricardo, fazem parte das ficções pobremente imaginadas do século XVIII; são robinsonadas". (MARX, 1990: 282)
}

R. Inter. Interdisc. INTERthesis, Florianópolis, v.6, n.1, p. 15-47, jan./jul. 2009 
individualizar-se na sociedade. A produção por parte de um indivíduo isolado, fora da sociedade - fato raro que bem pode ocorrer quando um civilizado, que potencialmente possui já em si as forças da sociedade, se extravia acidentalmente em uma região selvagem - não é menos absurda do que a idéia de um desenvolvimento da linguagem sem indivíduos que vivam juntos e falem entre si. (MARX, 1990, p. 283)

As relações sincrônicas fornecem a condição necessária e suficiente para cada indivíduo biológico ingressar na história. Assim, a horizontalidade das relações sincrônicas, ocorridas naquele mesmo tempo, fundamentam a verticalidade das relações diacrônicas entre indivíduos de épocas diferentes. É certo que a história é esse evolver diacrônico, vertical, porém ele é fundamentado pela ocorrência das relações sincrônicas que socializam os indivíduos horizontalmente. E esse é o mistério das condições humanas fornecidas a cada indivíduo biológico classificado como Homo sapiens. Para tanto, necessita-se da reprodução desse caráter de humano que ocorre no contágio sincrônico entre indivíduos. Cada indivíduo deve internalizar em si essas características. O Homo sapiens (a causa material, biológica, necessária) somente se torna humano se estabelecer vínculo societário com outros (a causa formal, a condição necessária e suficiente). ${ }^{7}$

Não importam quais qualidades genéticas, biológicas, tenha um bebê humano - por mais excepcionais que sejam - se for retirado de sua forma de vida histórica, de sua relação sincrônica com outros, esse bebê nem saberá balbuciar um pensamento e falar suas emoções e decisões. O seu idioma e sua capacidade de verbalização são sintomas de sua historicidade e não de sua materialidade biológica. O mesmo vale para sua escrita e para todo tipo de gramática que organiza sua oralidade, seus pensamentos e sua vida.

Arisco-me a fazer uma proposição: "tenho até dúvidas se esse bebê mantido isolado seria capaz de produzir alguma decisão e se poderia tornar-se hábil para conduzir sua existência". Evidentemente tal como é a longa e frágil infância humana, essa criança nem sobreviverá e essa minha proposição tem um efeito retórico. ${ }^{8}$

A aqueles que supõem que a diferença que identifica o humano dos demais animais seja sua criatividade em produzir a linguagem por sua mente excepcional e

\footnotetext{
${ }^{7}$ Aristóteles estabelecia 4 causas, nessa ordem crescente de importância: material, eficiente, formal e final.

${ }^{8}$ No século XIX tornou-se bastante comum as lendas de crianças que se perdiam da "civilização" e eram criadas por animais, lobos ou macacos; daí decorrem os personagens de Mowgli e de Tarzan. Eram tentativas de tornar "real" os mitos e as crenças iluministas do indivíduo racional, pleno de autonomia. No fundo são derivações das "robisonadas" criticadas por Marx.
}

R. Inter. Interdisc. INTERthesis, Florianópolis, v.6, n.1, p. 15-47, jan./jul. 2009 
por um aparelho fonador especializado, me contraponho. Muito limitado tentar entender a "natureza humana" olhando este animal individualmente, fazendo a "vivissecção epistemológica" de sua laringe para compreender a origem e a superioridade da sua linguagem em relação a dos demais animais. ${ }^{9}$ Ora a superioridade da linguagem humana encontra-se nas diversas funções sociais que ela cumpre, além de ser também a simples portadora de comunicação de eventos que se dão no mundo ou nas mentes. Mas a linguagem é muito mais do que um mero instrumento de comunicação entre as mentes dos indivíduos, de pensamentos que se pensariam antes de sua verbalização. Não se pode garantir nem a existência nem a independência dos pensamentos fora das estruturas linguísticas socializadas. A linguagem humana é constitutiva. Ela expressa as condições históricas de cada sociedade e transforma os animais biológicos em pessoas humanas.

A vida social é estruturada em relações complexas que estabelecem hierarquias, posições e lugares naturalizados. E a história não tem dúvidas em desenhar sociedades fundadas sobre tais relações de poder. Suponho que a linguagem seja o instrumento preferencial pelo qual o poder é exercido em sociedade e transforma uns humanos em senhores de outros, em sujeitos e também em sujeitos sujeitados - como foi mostrado por Hegel na sua Dialética do Senhor e do Escravo estabelecida na Fenomenologia do Espírito de $1807 .{ }^{10} \mathrm{E}$ isto é básico no entendimento da sociedade, não há uma idílica comunidade de iguais que partilham e somente comunicam idéias entre si. A linguagem não é um mero instrumento de simples comunicação, é uma feitora de estratificação e de naturalizações. Toda sociedade está assentada na desigualdade entre seus membros. A "superioridade" da linguagem humana está nesse poder que alguns indivíduos exercem por seu intermédio sobre outros e esse poder não está na laringe, não é o urro mais potente que fornece esse poder. Entre uma bio-linguística e uma linguística fisiológica prefiro

\footnotetext{
${ }^{9}$ Há um amplo debate nas pesquisas que pretendem desvendar as origens da linguagem. Entre os que privilegiam os estudos biológicos ou das ciências da cognição e aqueles que se voltam para a análise da pré-história há uma infinidade de propostas. O conflito básico de olhar está entre as tendências próximas de uma psico-linguística e a de antropólogos pré-históricos. Aqui me alinho com as ciências históricas e a orientação que compreende a linguagem como integrada à produção de ferramentas. Ver Handbook of human symbolic evolution editado por Lock e Peters. Em 1990 houve um importante encontro em Cascais, Portugal, entre os principais pesquisadores dessas áreas cujos artigos foram editados por Tim Ingold e Kathleen Gibson em 1993: Tools, language, and cognition in human evolution.

${ }^{10}$ Ver Alexandre Kojeve, 2002, e Jean Hyppolite, 1999. Esta perspectiva foi um instrumento para a análise semiológica que se construiu com Barthes e Pêcheux e que sustenta um olhar histórico para a linguagem.
}

R. Inter. Interdisc. INTERthesis, Florianópolis, v.6, n.1, p. 15-47, jan./jul. 2009 
ficar com Hegel para entender as relações humanas e o que é fundamento para o humano: o seu laço social que sujeita sujeitos. Está implícito em Hegel que este enlace entre o "senhor" e o "escravo" é dado pela linguagem. Prefiro ver a linguagem como laço social que hierarquiza seus usuários e os torna sujeitos. Prefiro Foucault para chegar perto das explicações que mostrem esse poder em ação localizado em indivíduos e situações concretas. Mesmo Marx, descartado atualmente, foi bem mais competente para falar das desigualdades intrínsecas entre os humanos estabelecidas por seus laços sociais do que a tal "vivissecção epistemológica" da laringe. A linguagem é um acontecimento societário, de poder. O formato da laringe humana simplesmente oferece as condições materiais necessárias para um animal emitir sons na variedade complexa que a linguagem humana solicita, e só. ${ }^{11}$

Nessa contraposição à compreensão da linguagem como a criação de mentes brilhantes de alguns indivíduos, e a seu corolário: de que humanidade é uma substância intrínseca ao Homo sapiens, inerente à sua racionalidade, já adianto que a linguagem humana é complexa e funcional o suficiente para ser muito mais ampla do que uma produção de qualquer indivíduo ou até mesmo para servir como código de comunicação em grupos de indivíduos. Entre a linguagem como invenção da mente de indivíduos e a linguagem como lenta construção histórica com o simples objetivo de comunicar idéias que a antecedem alinho-me com a perspectiva duplamente oposta a essas hipóteses mentalistas para a linguagem, não penso em uma linguagem criada pela mente do homem mas, sim, em uma linguagem que cria o homem. Linguagem como o fundamento último para a humanidade do homem, por fabricar o homem através de sua prática socializada.

\section{A HISTORICIDADE DO HUMANO: A PESSOA, O PÓS-SOCIAL E OS AGENCIAMENTOS}

No cenário da vida, o humano é uma distinção construída. Cada ser humano é um artefato produzido no seu particular devir histórico. Não se nasce humano, torna-se. Em história entende-se que cada indivíduo biológico, dito "humano", não nasceu assim. Ele tornou-se humano através de suas relações coletivas, societárias, em suas interações com o mundo. O humano não é um estado existencial biológico

\footnotetext{
${ }^{11} \mathrm{Na}$ falta da laringe e da vocalização os humanos ainda permanecem inseridos na linguagem, seja uma linguagem gestual ou de sinais, como é o caso dos surdos-mudos.
}

R. Inter. Interdisc. INTERthesis, Florianópolis, v.6, n.1, p. 15-47, jan./jul. 2009 
dado por uma tipologia inata ao ser. O humano é uma condição - uma condição histórica - do ser.

O ser torna-se humano ao se sujeitar ao processo histórico de humanização, um processo de vir-a-ser que o caracteriza e particulariza através da convivência e contaminação simbólica com os demais humanos. Humanização que inscreve cada indivíduo biológico no evolver constitutivo da humanidade. Aqui se confundem dois conceitos homônimos: humanidade como algo historicamente constituído - uma condição -, e humanidade como conjunto de indivíduos que formam uma espécie uma taxonomia de essências. O ser biológico denominado Homo sapiens é insuficiente para definir a qualidade humana que somente se dá no devir histórico, na existência concreta de cada indivíduo.

A animalidade do homem sofreu duas grandes transformações específicas. A primeira ocorreu na instância filogenética, de sua hominização biológica como antropóide, uma mutação física ocorrida durante milhões de anos que produziu uma espécie nova no gênero homo. Este animal, assim constituído, ingressou em um outro processo - mais recente, cerca de trinta mil anos - que instituiu a possibilidade de sua humanização. Enquanto que a hominização é de ordem material, genética, já na humanização há um tipo inaugural de mutação que ocorre na ordem simbólica. É uma "filogênese histórica" e desde então o animal Homo sapiens frequenta a história e conquista a condição de sua humanidade. Há alguns milhares de anos o animal meramente biológico "inventou" a história e nela vem se desenvolvendo.

Mas para que esse processo amplo ocorra na espécie é necessário que cada indivíduo receba o batismo da história e que, assim, se torne um sujeito simbólico, isto é, que participe - agora na instância ontogenética - da herança histórica depositada em sociedade. Cada indivíduo, cada espécime do gênero homo, necessita repetir em seu devir particularizado o roteiro filogenético que o gênero homo percorreu, necessita reproduzir em sua existência individual - ontogenética as qualidades culturais alcançadas pela espécie no devir mais amplo de sua "filogênese histórica". Isto é básico e elementar como condição histórica. A humanização de cada indivíduo é consequência de sua historicidade, de sua vivência simbólica em uma cultura, da forma de vida que vivenciará em sociedade. Cada bebê humano somente se constituirá como tal se seus primeiros anos de vida permitirem sua entrada no registro simbólico, se a sua convivência com os humanos já constituídos Ihe abrir as portas de uma historicidade constitutiva de sua R. Inter. Interdisc. INTERthesis, Florianópolis, v.6, n.1, p. 15-47, jan./jul. 2009 
humanização. Não importa qual a cultura, o indivíduo somente se faz humano ao se tornar um sujeito histórico, ao estabelecer laços societários com os demais.

Este laço social é um vínculo instaurado no espaço simbólico da cultura que coage, sujeita os indivíduos e os torna sujeitos. Assim o animal humano se constitui em uma pessoa humana. A categoria de "pessoa" é básica para caracterizar a humanidade desse ente simbólico-material, ${ }^{12}$ um sujeito histórico sujeitado às suas condições de historicidade. Mas o que é uma pessoa? A pessoa possui uma história de vida, uma nacionalidade, fala um idioma, admite um conjunto de crenças e valores, ingressa no plano ético, enfim, se humaniza. A categoria de "pessoa" retira os indivíduos do espaço meramente biológico e os reconhece como sujeitos. A pessoa é a condição de humanidade adquirida pelos indivíduos biológicos decorrente de seus agenciamentos no mundo, é um constructo social que garante a humanização de cada indivíduo. A pessoa não nasce como tal, é um artefato construído ao longo de sua história. Ingressa no registro simbólico e torna-se um falante que se expressa simbolicamente. Cada pessoa fala. Fala um idioma. Fala para outra pessoa. Pessoa é uma entidade simbólica, uma habitante do espaçotempo cultural, um falante.

E para além de um modelo bio-mecânico para o humano há ainda outra consideração necessária. Após as experiências históricas do século passado - na psicanálise, no estruturalismo lévi-straussiano, na semiologia e no pósestruturalismo - não há mais plausibilidade para se pensar em um humano típico do oitocentos. Um ser volitivo e racional, plenamente consciente de suas necessidades materiais e que age movido por suas decisões voluntariosas com a finalidade de atender essas necessidades. Tudo muito coerente porém ficcional. A pessoa que pensamos desde meados do século XX é bem diversa. Muito mais ambígua e inconsistente em seu agir no mundo, um agir reativo ao seu meio em confronto com suas vivências culturais. Atende a necessidades materiais e a "necessidades" simbólicas, isto é, a desejos. Há necessidades e há desejos. ${ }^{13}$ Pensamos a pessoa como um animal simbólico e desejante, uma estrutura movida por algo bem mais

\footnotetext{
${ }^{12}$ Tim Ingold. "Humanidade e Animalidade", 1999, In: Revista Brasileira de Ciências Sociais no. 28.

${ }^{13}$ Uma articulação entre os conceitos de "desejo" e de "necessidade" é estabelecida por Marx na segunda nota ao Capital, que sugere a proposta do desejo abarcar a necessidade. Marx analisa ainda a mercadoria como objeto das necessidades humanas e trata da sua relação com o desejo. A mercadoria como laço societário. E o "desejo envolve necessidade" diz-nos Marx, a mercadoria "satisfaz necessidades humanas, seja qual for a natureza, a origem delas, provenham do estômago ou da fantasia". Karl Marx. O Capital. Rio de Janeiro: Civilização Brasileira, 2002, Vol I. p. 57 nota 2.
} 
complexo do que aquela simples e plena consciência racional. Movimenta-se por algo que vai além de suas necessidades biológicas. A pessoa não é definida só por suas necessidades materiais, mas pela instância simbólica, por seus desejos. O desejo abarca a necessidade, ou seja, o simbólico envolve o material.

Considerava-se a necessidade como algo material e "natural", prédeterminado e que já estaria lá - no organismo e no mundo, como a fome e o frio -, mas já o desejo passa por uma criação simbólica contínua, inventa-se um novo desejo a cada dia; diz-se: o desejo cria necessidades. O desejo é sedução do querer, é ponto de partida da movimentação das pessoas no mundo. Cada pessoa é uma entidade eminentemente simbólica, deseja através do simbólico. Movimenta-se por seus desejos, fala seus desejos, deseja através de sua expressão simbólica. Fala por significações desejantes. Trata-se de um ente constituído na e pela linguagem, enlaçado socialmente através da linguagem. Não uma linguagem como mera transmissão de idéias que já estariam na consciência individual. Mas linguagem como produção de idéias desejantes. Uma linguagem considerada como laço societário. Como aquilo que une um humano a outro, que os faz humanos e, assim, tornam-se pessoas simbólico-desejantes. São sujeitos sujeitados à linguagem. Cada pessoa fala seus desejos e se torna sujeito desses desejos que a sujeitam.

E aqui necessitamos de outros instrumentos operacionais para seguirmos adiante. Até o momento situamos o humano em sociedade mas isto ainda é insuficiente. O humano emerge na clivagem de dois mundos. Ele é um misto de natureza e cultura. $\mathrm{O}$ animal humano em estado de natureza somente reconhece suas necessidades materiais, já a dimensão simbólica ocorre quando esse animal humano entrar em uma cultura. Mas não há como separar esses dois registros: o da sociedade e o da natureza. Eles estão imbricados. Só conhecemos humanos que vivam simultaneamente na materialidade natural e no espaço simbólico da sociedade.

A natureza do homem está integrada à natureza das coisas. Assim se recuperam e intensificam clássicas propostas já anunciadas pelas "teorias" da prática que, ainda no século XIX, partiam do pressuposto de analisar a ação humana desde seus primeiros princípios, ou seja, a vida e a história humana consideradas como uma questão de sobrevivência. Dessa forma, descortinamos o movimento 
inaugural da história: os homens buscam satisfazer suas necessidades de sobrevivência ao trabalharem a natureza.

O homem necessita, em primeiro lugar, comer, beber, ter um teto e vestir-se antes de poder fazer política, ciência, arte, religião etc.; a produção dos meios de vida imediatos, materiais (...) é a base a partir da qual se desenvolvem as instituições políticas, as concepções jurídicas, as idéias artísticas e inclusive as idéias religiosas dos homens e com relação à qual devem ser explicadas, e não o contrário (ENGELS, 1974, p. 171-172) ${ }^{14}$

A separação natureza-sociedade é um dos principais instrumentos que alimentam os equívocos da compreensão idealista e também da substancialista do humano. Em uma compreensão pragmática da história - tal como a que abraçamos aqui - é essencial que se entenda o estar no mundo dos homens como um processo interativo desses homens com as partições desse mundo: a sociedade e a natureza. Sociedade e natureza estão integradas e as ações humanas ocorrem entre esses dois setores, separados meramente por analiticidade compreensiva. A sociedade não tem vida própria, independente da natureza. Uma sociedade é delimitada através das maneiras pelas quais o homem intervém no mundo natural. Pedra lascada e pedra polida indicam eras históricas caracterizadas pela forma interativa através da qual os homens integraram natureza e sociedade.

Isso nos encaminha para a hipótese do "pós-social" de Karin Knorr Cetina. ${ }^{15}$ "Social" é um termo usual na sociologia e na história para pensar simplesmente os humanos entre si. Necessitamos de mais, necessitamos incluir neste "social" as relações materiais com o mundo. Quando pensamos em "social" consideramos que o único agente transformador é o humano, com sua intencionalidade e volição. Ora, há parceiros nos agenciamentos que ocorrem no mundo. O homem não é o único agente que produz eventos. Os eventos do mundo são múltiplos e complexos. Em geral, o papel do humano é reativo ante as delimitações impostas pelo mundo natural. Antes de ser meramente um vivente ele é um sobrevivente, sobrevivente às condições de contorno que o mobiliário do mundo natural impõe a seu cenário de vida.

O próprio indivíduo humano já traz em si essa necessária reunião entre o natural e o simbólico da cultura. Afinal, o humano simbólico é também um corpo, é

\footnotetext{
${ }^{14}$ Trecho de seu discurso no enterro de Marx. ENGELS, Friedrich. Discurso ante la tumba de Marx. In: Marx y Engels: obras escogidas, vol. III. Moscú, Editorial Progreso, 1974.

${ }^{15}$ Ver Karin Knorr Cetina $(1997,2000)$ e também Scott Lash (2001) que trata de "formas tecnológicas de vida", um adendo útil para a hipótese "pós-social" de Cetina.
}

R. Inter. Interdisc. INTERthesis, Florianópolis, v.6, n.1, p. 15-47, jan./jul. 2009 
um animal. Rigorosamente não é possível separar essas instâncias, nem na esfera do indivíduo nem na das coletividades. A ultrapassagem efetiva da ruptura entre natureza e sociedade exige que se compreenda um "pós-social". O conceito clássico de "social" é restritivo, já pressupõe a separação mítica entre sociedade e natureza, entre o homem e as coisas do mundo com uma clara superioridade humana implícita. O "social" é exclusivo para pensar as relações de homens entre si, porém os humanos sempre estão em um cenário que os coage e se infiltra nas relações com outros homens. A ultrapassagem da separação entre natureza e sociedade que nos traz a noção de "pós-social" exige que se incluam nos agenciamentos tradicionais e usuais da sociologia - dos atores sociais - todas as formas de agência material. A noção de agência não pode ficar confinada às volições e intenções humanas. ${ }^{16}$

Nesse novo quadro conceitual é que pretendo analisar a linguagem, extraindo-a do entendimento do idealismo humanista do lluminismo que a tomou como qualidade racional e fundamento do humano. Podemos até prosseguir com o mito de que a linguagem é a característica definidora do humano mas isso deve ser posto na cena mais ampla que incorpore no devir histórico todas as formas de agência, inclusive a da própria linguagem: a linguagem como agência.

\section{MAS, AFINAL, O QUE É A LINGUAGEM COMO AGÊNCIA?}

Nas suas demandas de sobrevivência todo animal entra em relação com o mundo que o rodeia. Esta relação é denominada de agência. Toda agência é "intraativa", como diz Karen Barad, ela ultrapassa a mera função interativa. Isto é, a agência é constitutiva das partes aí e assim envolvidas, é a forma de relação pela qual cada ser se faz e se refaz continuamente. ${ }^{17} \mathrm{Na}$ agência é que os seres ganham suas existências. Existir é agenciar. ${ }^{18} \mathrm{~A}$ fenomenologia da existência é a fenomenologia da agência.

\footnotetext{
${ }^{16}$ Tal como acontece nas teorias de estrutura e agência usuais na sociologia nas quais a agência é tomada como atividade estritamente humana, ver Giddens, 1979.

${ }^{17}$ Karen Barad, 1999, 2001, 2003 e 2007.

${ }^{18}$ Quando um indivíduo confecciona uma lança a partir de um galho de arbusto ele está em agência com o arbusto e a ontologia desse ramo de árvore transforma-se na de um artefato, uma arma; já o simples indivíduo agora é um caçador. Caçador e arma são novas entidades constituídas pela agência. Existem por estarem em interação através da agência.
}

R. Inter. Interdisc. INTERthesis, Florianópolis, v.6, n.1, p. 15-47, jan./jul. 2009 
No caso do humano, um animal gregário, sua característica determinante é de que as agências nas quais está envolvido passam por práticas compartilhadas. ${ }^{19}$ Sua existência ocorre no interior do grupo ao qual pertença, através de vivências comuns - são práticas herdadas e transmitidas que estabelecem contornos para o agir coletivo. Essa herança de práticas é interiorizada por cada membro do grupo que as toma como suas e as emprega em seus agenciamentos no mundo. As práticas bem sucedidas são fixadas no grupo e tornam-se de uso socializado. Este procedimento receptor-transmissor constitui o fundamento para tornar o humano um animal histórico. Assim ocorre o devir histórico: na reprodução contínua de vivências pré-existentes, nas transformações e inovações estabelecidas e que se fixam e transmitem dentro do grupo. Cada indivíduo vive em acordo com as práticas já instituídas no grupo. Ou seja, a práxis já ocorre em condições históricas dadas.

Essa condição histórica do humano encontra-se bem analisada em LeroiGourhan que já estabeleceu como os hominídeos primitivos realizavam seus agenciamentos através de uma rotina de procedimentos práticos, tanto para a confecção como para o uso de ferramentas e utensílios. Tais procedimentos partilhados pelo grupo e internalizados por cada membro ativo pressupõe que esses hominídeos reproduzam e transmitam essas práticas através das quais operam seus agenciamentos.

O emprego de algum instrumento, uma ferramenta, implica em seguir um conjunto de pequenos atos articulados entre si, isto é o "seguir uma regra" de Wittgenstein. São ações sucessivas que apresentam uma lógica para a fabricação e para a utilização do artefato - por exemplo, a escolha e coleta de um arbusto para a confecção de um arpão e a técnica de sua manipulação no ato de pescar. São operações encadeadas - "cadeias operatórias" - associadas à cada agência específica, à cada utensílio/ferramenta, e que se constituem elas próprias em uma técnica bem estabelecida. São sequências operacionais que impõem uma abstração simbólica para apreender a materialidade da técnica. Assim, uma determinada ação está vinculada a um agente material, um utensílio, mas esse próprio instrumento solicita que haja uma ação compreensiva para sua utilização, uma ação que capture e reproduza a lógica da sequência operacional. O utensílio vai além de sua

\footnotetext{
${ }^{19}$ Em nossa percepção pragmática é central o entendimento de que as práticas compartilhadas definem a atividade humana. Veja também o conceito de "comunidade de práticas" em Ahearn, 2001: 127.

R. Inter. Interdisc. INTERthesis, Florianópolis, v.6, n.1, p. 15-47, jan./jul. 2009
} 
concretude, ele solicita a apreensão de sua "sintaxe operatória", da sua lógica de funcionamento, para se transformar em objeto utilitário comum e de uso continuado no grupo social.(LEROI-GOURHAN, 1990, p. 116-117)

Tratam-se de uma "cadeia operatória" e de uma "sintaxe", ambas, simbólicas. Apreender a sintaxe de uma cadeia operatória é capturar a gramática associada a cada artefato produzido, é compreendê-la e internalizá-la como uma operação simbólica. O modus operandi de cada artefato, seja ferramenta ou utensílio, é a essência do processo de agência - é o elemento significante da operação - que deve ser explicitado como um registro da sequência operacional no espaço simbólico. É necessário que se saiba reproduzir em uma linguagem esta gramática dos objetos - o texto da agência. Um determinado instrumento material é inseparável do procedimento que Ihe dá sentido, que lhe propicia uma significação. Cada agência envolve um instrumento concreto e também a assimilação de suas técnicas de utilização, ou seja, a agência já opera no espaço simbólico, ela se expressa através de códigos simbólicos comuns que retêm e difundem sua "sintaxe" de funcionamento. A sintaxe operatória é traduzida em símbolos que conformam a expressão linguística daquela operação. Gordon Hewes trata dessa vinculação entre linguagem e ferramentas em "A history of speculation on the relation between tools and language" mostrando a via de mão dupla que ocorre:

A conexão tem sido vista ou como a linguagem primitiva contribuiu materialmente para o aparecimento da fabricação e uso de ferramentas humanas, ou então que a linguagem foi uma das consequências das fabricações e dos usos das ferramentas mais avançadas nos primeiros hominídeos. (HEWES, 1993, p. 20, Tradução minha)

Assim, através dessa associação com os conceitos de cadeia e sintaxe operatórias, Leroi-Gourhan nos conduz para a hipótese da produção simultânea da linguagem e do uso das técnicas instrumentais. "O homem fabrica utensílios concretos e símbolos, uns e outros resultantes do mesmo processo".(Leroi-Gourhan, 1990: 116) Afinal, para Gourhan, "não há razão para separar, nos estádios primitivos dos antropídeos, o nível da linguagem do utensílio", e no evolver histórico do homem “o progresso técnico está ligado ao processo dos símbolos técnicos da linguagem", no qual parece haver uma articulação sincrônica entre a linguagem e as técnicas utilizadas, que se desenvolvem interativamente, em unidade, como um conjunto, e assim pode-se associar "aos australopitecos e aos arcantropos uma linguagem de 
nível correspondente ao dos utensílios". (LEROI-GOURHAN, 1990, p. 117, grifos meus)

Essa produção sincrônica da linguagem e das técnicas constitui a própria linguagem como parte da técnica utilizada. E mais, é uma produção que integra em correspondência - um determinado nível de técnica com um nível equivalente para a linguagem. Técnica e linguagem caminham emparelhadas, pari passu. Para um patamar de complexidade da técnica solicita-se um correspondente patamar de abstração para a linguagem. O desenvolvimento da linguagem humana seguiu os passos da crescente sofisticação técnica. Técnica e linguagem integradas: uma solicitando a cooperação da outra. A linguagem é a fiel depositária das sintaxes apreendidas, pois "as operações de fabrico preexistem no momento de sua utilização e porque o utensílio persiste para ações posteriores." Assim, a insistência e permanência de um conceito expresso pela palavra é comparável ao emprego do utensílio, ambos - linguagem e ação material - participam da confecção e uso do artefato. (LEROI-GOURHAN, 1990, p. 117)

Esse é o papel fundante da linguagem, um papel constitutivo da agência. ${ }^{20}$

A linguagem participa e complementa a materialidade da ação, em sua concretude, ao forjar as significações da agência dando-lhe sentido, guardando esse sentido. Uma ação sempre é acompanhada de sua significação, não se habita em um caos de ações sem significados agenciadores. A linguagem integra a agência em sua essência, em sua natureza simbólica e estabelece a lógica e a sintaxe da ação. A linguagem fornece os contornos que definem a agência como recurso simbólico-material necessário para movimentar o existir, histórico, por excelência.

Aprender habilidades é uma ação executada no espaço simbólico pois a cada nova vez que se repete a operação implica em reter o significado já estabelecido, ou melhor, implica em refazer uma significação anteriormente socializada. O artefato material de uma agência somente é constituído em seu uso concreto. Tanto o

${ }^{20}$ A proposta sincrônica da linguagem e da técnica de Leroi-Gourhan segue de perto a do antropólogo russo Viktor V. Bunak, L'origine du langage, in Les processus de l'hominisation. Colloques Internationaux du CNRS, Les Sciences Humaines (Paris 19-23 mai 1958), Paris 1958, 99111. Ver Leroi-Gourhan, 1990: 116-119, 220. Esta associação entre utensílios, práticas e linguagem funda a compreensão de que há uma "cadeia operatória" que organiza gestos, representações simbólicas e os utensílios - em sua fabricação e uso - em uma "sintaxe operatória". Esta lógica operacional associada aos artefatos e que constitui a técnica encontra-se fundida com o próprio uso da linguagem.

Há duas tendências para explicar a origem da linguagem, uma que prioriza a produção de sons para o falar e outra que se apoia nos gestos, no visual, como a base originária da linguagem. Há também aqueles que procuram uma integração entre ambas perspectivas, como trata Stephenson, 1980.

R. Inter. Interdisc. INTERthesis, Florianópolis, v.6, n.1, p. 15-47, jan./jul. 2009 
procedimento de uso quanto o próprio "corpo" do utensílio, em sua materialidade, constituem o tal artefato. Uma ferramenta é composta por ambos, a sua materialidade e a sua significação simbólica. Ambas necessitam ser fixadas e reproduzidas no grupo. São operações simultâneas, inseparáveis.

Nesse processo interligado entre o material e o simbólico, as práticas compartilhadas se desdobram em significações igualmente compartilhadas, são práticas discursivas. Toda ação está envolvida por um sentido que lhe dá um motivo, são ações motivadas por uma teia de significações. ${ }^{21}$

A socialização que ocorre nesta reprodução, na interiorização das regras, dos usos e dos procedimentos para as habilidades técnicas, é sustentada por elementos simbólicos. Esse conjunto de técnicas simbólico-materiais constituem laços que consolidam indivíduos em práticas compartilhadas no grupo. São práticas que permanecem no grupo, como características históricas do grupo continuamente reproduzidas. Renovam-se na memória. Assim, a permanência de um instrumento, de um utensílio, de uma técnica, é da mesma ordem da persistência de uma operação simbólica. A cadeia operatória e sua sintaxe sobrevivem na memória histórica do grupo. Esta a noção de dizer-se que a técnica é tanto simbólica quanto material. A linguagem é constitutiva das ferramentas e utensílios, ou seja, a linguagem é ela própria uma ferramenta, uma forma de ação no mundo. A ligação entre técnica e linguagem ocorre pois "a técnica é simultaneamente gesto ou utensílio, organizados em cadeia por uma verdadeira sintaxe que dá às séries operatórias a sua fixidez e sutileza." (LEROI-GOURHAN, 1990, p.117). Em todo fazer há um saber-fazer que pode ser expresso em um dizer. Fabricar ferramentas e utensílios é também "fabricar" um procedimento de comunicação simbólica o qual denominamos de linguagem.

Esta é mais uma razão para fortalecer a compreensão de uma correspondência entre o nível da técnica e o da linguagem. Cada fazer solicita um dizer que Ihe equivalha. Estima-se que há uma necessidade do desenvolvimento típico para a linguagem na fase do paleolítico e que é diferente e menos elaborado do que a do fim do neolítico. A demanda técnica por uma linguagem estabelecida no neolítico apresenta complexidades crescentes que não ocorriam no paleolítico. Há

\footnotetext{
${ }^{21}$ Tal como pensar a agência através de "práticas compartilhadas" (shared practices), compreender essa atividade como de "significações compartilhadas" (shared meanings) constituem elementos indispensáveis para nosso olhar pragmático que incorpora a linguagem como agência.
}

R. Inter. Interdisc. INTERthesis, Florianópolis, v.6, n.1, p. 15-47, jan./jul. 2009 
uma correspondência: uma técnica, uma linguagem. Neste evolver dos processos linguísticos, o surgimento da escrita ocorrerá num momento tecnicamente compatível com esta forma de expressão das significações socialmente necessárias. O evolver técnico é acompanhado por um evolver equivalente da linguagem, das significações das agências e práticas socializadas. A operação de significar algo do mundo decorre de um agenciamento dos sujeitos com os seus pretensos objetos, o mundo. A constituição simbólica do mundo como artefato através de um léxico, de uma sintaxe e de uma gramática, é o coroamento dessas agências nas quais a linguagem é sempre uma participante essencial.

Não conheço outra hipótese explicativa mais consistente para a formação da linguagem do que esta proposta etnográfica que a situa como prática histórica efetiva. O modelo mentalista para a linguagem carece de qualquer fundamentação histórica. É uma representação erigida na Antiguidade e que se fortaleceu na Idade Média, uma representação que precisa ser revisada e que possui todas as características de um mito. Um mito que exige um movimento iconoclasta para desvencilhar as ciências sociais do seu último e derradeiro reduto que propõe a ruptura entre o mental e o material, entre a natureza e a sociedade. A linguagem se constituiu em uma prática coletiva de interação com o mundo natural. É uma prática discursiva, é uma prática e também um discurso. "Práticas discursivas produzem, mais que meramente descrevem, o "sujeito" e o "objeto" das práticas de conhecimento". (BARAD, 2003, p. 818, tradução minha)

As práticas discursivas e os fenômenos materiais não estão em uma
relação de exterioridade, um para o outro; ou melhor, o material e o
discursivo implicam-se mutuamente pela dinâmica da intra-atividade. Mas
não são redutíveis um ao outro. A relação entre o material e o discursivo é
de implicação recíproca (...) matéria e significação estão em articulação
mútua. Nem as práticas discursivas nem os fenômenos materiais são
ontologicamente ou epistemologicamente prévios. Nenhum pode ser
explicado em termos do outro. Nem possui status privilegiado na
determinação do outro. (BARAD, 2003, p. 822, tradução minha)

Esse conjunto de argumentos sintetiza aquilo que designei como pós-social. O termo "pós-social" indica a necessidade de se expandir a nomenclatura de "social", e claro, os conceitos e percepções a ela associados. O social tal como era compreendido classicamente nas ciências sociais: um social que se satisfaz com a percepção de humanos isolados entre si e que implica na separação entre 
sociedade e natureza, uma sociedade extraída do seu contexto, do ambiente no qual ela própria e as pessoas se reificam. Mas isto é uma fiç̧ão. Não existe a sociedade composta exclusivamente por humanos. Sempre há um ambiente, um contexto material contra o qual a sociedade reage. A história e a sociologia estão habituadas a conceituar o social como a relação entre os homens e aí se situarem comodamente. É uma simplificação grosseira. É uma semântica equivocada - o social deve incorporar o cenário no qual os homens vivem, o ambiente no qual se desenvolvem as relações humanas. As relações humanas são amplas e variadas em suas inúmeras facetas. Há relações estritamente interpessoais e há relações promovidas com as coisas, ambas são vitais. O corte natureza-sociedade produz diversos equívocos e dá sinais de seu esgotamento. Hoje há tendências em história e em sociologia que já despertaram para essa lacuna conceitual, mas ainda são marginais. Tratam-se de uma história e de uma sociologia ambiental. ${ }^{22}$

Quando Knorr Cetina lançou a hipótese do "pós-social" ela estava avaliando nosso momento de aceleradas transformações nas quais, cada vez mais, os humanos estão envolvidos com relações objetais e constituem o que Lash denomina de novas "formas tecnológicas de vida" (LASH, 2001). As relações materiais das pessoas são crescentes e solicitam uma mudança de perspectiva em ciências sociais:

[...] a noção de uma sociabilidade com objetos requer uma extensão, se não uma ampliação da imaginação sociológica e do vocabulário. Se o argumento sobre uma transição pós-social contemporânea estiver correto, essas extensões deverão ser necessárias em vários aspectos; fazê-las é possivelmente o principal desafio que confronta a teoria social hoje. (CETINA, 1997, p. 2, tradução minha)

\section{A LINGUAGEM, UMA PRÁTICA COMPARTILHADA QUE EXPRESSA UMA SINTAXE E UMA TAXONOMIA PARA O MUNDO}

Assim, ao ser protagonista em um conjunto de agências, cada membro de um grupo participa de uma certa quantidade de práticas compartilhadas, das diversas

\footnotetext{
${ }^{22}$ Ainda que o movimento ambientalista da década de 1970 tenha induzido o aparecimento de uma História Ambiental, hoje as perspectivas tanto em sociologia quanto em história, ambientais, estão atentas para a renovações teóricas e mostram a inclusão das relações materiais nas chamadas relações sociais. Estamos cada vez mais envolvidos com a agência material das coisas do mundo.
}

R. Inter. Interdisc. INTERthesis, Florianópolis, v.6, n.1, p. 15-47, jan./jul. 2009 
cadeias operatórias que são necessárias para a sobrevivência individual e coletiva. Isso produz uma arquitetura simbólico-material de significações comuns para o grupo e desenha uma maneira pela qual seus membros vivem e sentem o mundo, desenha uma "forma de vida" wittgensteiniana. Define o que é o humano naquele momento histórico. A trama de cadeias operatórias utilizadas estabelece uma percepção do que seja o mundo e de como agir nesse mundo. $O$ mundo se apresenta como um feixe de agências que expõe significações para seus usuáriosagentes, são significações que constituem uma linguagem. ${ }^{23} \mathrm{O}$ mundo não é mais um "mundo natural", um fotograma de um objeto distante, afastado do sujeito que o habita, mas é um artefato simbólico que envolve o sujeito. $\mathrm{O}$ mundo é definido e expresso pelas significações linguísticas. É uma extensão do sujeito. Sujeito e objeto estão enfim amalgamados, estão postos juntos na cena, estão superpostos, entretecidos pela linguagem. Nesse estágio, a historicidade de um certo membro do grupo é dada pelo conjunto articulado de agências que compõe e rege a sua vida naquele grupo. Ele age e percebe o mundo através de sua historicidade, das significações disponíveis e que estão enfeixadas por essa trama de agências. Tais agências se compõem de práticas que são, reciprocamente, significações partilhadas. O Mundo é um constructo simbólico, é constituído por aquilo que é dado pela linguagem.

Essas significações - que dão forma e cor ao cenário do mundo - fornecem uma orientação prático-simbólica para aquela "forma de vida" viver sua vida, para sua existência e andanças nesse mundo. Aquela parcela do mundo que não participa dessas agências é percebida de maneira diferente, chega a ser desconsiderada por não integrar os interesses e motivos daquela "forma de vida". É aquilo que Derrida (1999) denomina "traço", um traço imotivado que ainda não recebeu o significado, ainda não se tornou uma inscrição. É uma parte do mundo que perde visibilidade e não adentra o sistema simbólico das significações instituídas. Torna-se um significante sem significado. As agências fornecem percepções seletivas. A natureza não é olhada como um todo homogêneo. Essas diferenças de "visibilidade" produzirão uma taxonomia. Estabelecem para o mundo uma grade de significações diferenciadas. Na natureza do mundo somente ganham destaque aquelas entidades, aqueles significantes, que já integram o sistema

\footnotetext{
${ }^{23}$ Essa forma de articular Wittgenstein com a noção de agência é essencial para nossa compreensão pragmática que inclui o "seguir uma regra" como fundamento de uma etnografia.
}

R. Inter. Interdisc. INTERthesis, Florianópolis, v.6, n.1, p. 15-47, jan./jul. 2009 
simbólico, que já possuem significados naquele grupo, que se tornaram significantes nas práticas de agências vividas naquele grupo. $O$ olhar dirigido ao mundo filtra, recorta o que deve e pode ser visto. O cenário do mundo recebe iluminação desigual, boa parte desse cenário permanece na penumbra dos interesses. Delimitase e foca-se a cena através desse perceber dirigido, orientado e engendrado na historicidade de seus agenciamentos anteriores e articulados entre si. É um ver seletivo ou como dizia Fleck, um "ver formativo" - um Gestaltsehen, que igualmente é também uma recepção simbólica. Percebem-se umas formas e não outras. ${ }^{24}$

Há um acervo de significações já estabelecidas na memória e que fornecem o repertório interpretativo no qual os eventos do mundo são codificados. Um novo acontecimento será examinado em contraste com esse acervo passado, será reconhecido como parte do texto dos significantes já incorporados. Ou seja, a compreensão do novo depende do "saber" constituído pelas práticas consolidadas. O léxico das práticas vividas estabelecem o aparelho simbólico - o Gestaltsehen pelo qual o grupo se adapta e reage ao devir do mundo. Pelo qual o grupo detecta, decodifica e fala dos eventos do mundo. Os membros do grupo, ao ampliarem suas vivências, seu léxico de práticas, incorporam novas experiências significativas e estabelecem, assim, novos saberes.

As coisas do mundo afetam, sensibilizam os humanos segundo esse repertório. Se já integram o acervo de práticas anteriores - isto é, se já integram a historicidade daquele corpo sensível a essas coisas - então serão sentidas em acordo com este léxico historicamente constituído e teremos uma percepção, como analisa Merleau-Ponty (2006) em sua fenomenologia, porém, se estiverem fora desse espaço das significações pregressas, abrir-se-á um dilema. Ou serão ajustadas, por algum tipo de similaridade às já vivenciadas, ou permanecerão insignificantes, à espera de uma definição sensório-compreensiva. Cada evento no mundo não se traduz automaticamente em uma percepção, mas será uma recepção sensória de algo indefinido, um estímulo ainda não significado - o tal traço imotivado derridiano. O traço emerge nas diferenças sensórias, como pura diferença. É o sintoma das diferenças estabelecidas nas atividades sensórias e nas percepções. Marcando a distância entre o traço e a percepção há o motivo significante de algo

\footnotetext{
${ }^{24}$ Em Fleck (1979) é indispensável que se compreenda as atividades cognitivas como produzidas por práticas compartilhadas em um grupo. Há um "estilo de pensamento" associado a um "coletivo de pensamento". O estilo de pensamento, Denkstil, é a expressão dos contornos que a linguagem impõe ao modo de agir societário e permite um Gestaltsehen.
}

R. Inter. Interdisc. INTERthesis, Florianópolis, v.6, n.1, p. 15-47, jan./jul. 2009 
que já frequenta o espaço simbólico das significações instituídas. Ao vencer essa distância, o traço abre-se ao Gestaltsehen, à linguagem. Somente através desse processo o traço encontra seu vir-a-ser percepção. ${ }^{25}$

Por esse instrumento o humano se transforma em um arquiteto para o mundo, ele classifica e desenha o mundo segundos suas percepções. O mundo fica dividido e subdividido em categorias classificatórias e o humano produz uma taxonomia para esse mundo em acordo com sua base cultural. Tal como os clássicos da sociologia e da etnologia propuseram. Podemos até definir o humano como aquele que apresenta o mundo como artefato de seu aparelho simbólico, o Gestaltsehen, como aplicação e exemplo comprobatório da veracidade de sua cultura. O humano como xamã do seu mundo-artefato.

As coisas igualmente atuam sobre as pessoas, sim, porém, em geral a cena da agência ocorre no espaço simbólico. As coisas do mundo afetarão os humanos justamente por elas invadirem o seu espaço simbólico e aí ganharem uma significação. Sem esta significação, o mundo se apresenta como um conjunto amorfo de simples traços, vestígios de algo indeterminado, sem sentido algum, um deserto para o sedento, um texto para o analfabeto. São traços de algo incógnito, estão fora da linguagem. Para que a coisa possa interagir com uma pessoa deve poder transformar seu simples traço em uma inscrição "legível" para aquela pessoa, sem isso o traço passa despercebido.

Diremos com Derrida, que as coisas afetam as pessoas ao receberem uma significação dada por aquela cultura, tornarem-se inscrições para aqueles sujeitos, frequentarem a linguagem. Esse é o momento em que o mundo "real" invade a cena de vida de cada pessoa e se apresenta à realidade humana, histórica. Configurou-se uma agência material. E nesta agência nos situamos e nos desenvolvemos como pessoas determinadas. A história de vida de cada indivíduo é a história das agências nas quais cada um se envolveu. Tal como a história de uma sociedade também é a história das agências materiais que formam a sua cultura. A humanidade do homem encontra-se especificada e garantida por seus agenciamentos recíprocos.

\footnotetext{
${ }^{25}$ Esta articulação entre o "traço" derridiano e a fenomenologia da percepção de Merleau-Ponty (2006) e destes com a sociologia do conhecimento de Fleck é de minha responsabilidade. Proponho que enquanto pura diferença sensória o traço imotivado ainda não está constituído em uma percepção, não ganhou um sentido, é um estímulo de mera diferença sensível. Somente ao ingressar na historicidade do ser é que o traço origina uma percepção. E este ingresso se dá por o traço ganhar uma significação no contexto de um estilo de pensamento fleckiano.

Sobre a apropriação de Derrida veja Maia, 2006, "A materialidade da linguagem na história e na ciência" e Maia, 2008, "Diferença, traço e inscrição: Derrida e a escritura cognitiva do mundo".
}

R. Inter. Interdisc. INTERthesis, Florianópolis, v.6, n.1, p. 15-47, jan./jul. 2009 
Cada indivíduo age no mundo e o percebe através da trama de agências que constitui o âmago de suas vivências e estabelece a sua historicidade e sua linguagem. Essa prática do seu viver lhe permite um entendimento do mundo - e também de si e de seus pares sociais - e lhe justifica uma avaliação normativa sobre seu próprio agir. Ele já traz incorporado em seu modo de ser o conjunto de normas e significações socialmente partilhadas - são valores, comportamentos, atitudes, juízos éticos e estéticos. Através dessa internalização ele classifica, constrói uma taxonomia para as coisas do mundo, para o mundo.

Assim, desde a pré-história, há uma forte conexão entre o saber e o fazer. $A$ cognição emerge como decorrência das práticas de ação no mundo, elas conjugam as formas de percepção do mundo associadas aos agenciamentos. Do ponto de vista da compreensão pragmática aqui exposta, o conhecimento não é caracterizado como uma produção estritamente mental como o logocentrismo iluminista propõe. Nem é movida por um motor, a Razão, uma essência que faz o animal humano alcançar um estado "iluminado" de humanidade mítica. A "razão" não é uma entidade endógina do ser humano mas decorre do processo histórico que o constitui como "ser racional". Antes de ser o motivo que explique o evolver do gênero homo, a "razão" necessita ser explicada por este evolver, provavelmente, talvez, como uma estratégia eficaz de intervenção no mundo. Assim, o tal homo se fez através de suas agências, de suas práticas discursivas.

Considere-se que as características biológicas desse animal designado como Homo sapiens são basicamente as mesmas desde o seu alvorecer na história. Entretanto, a maneira pela qual ele realiza seus agenciamentos sofreu grandes alterações. A filogênese do gênero - como já dissemos, que durou milhões de anos - alcançou o seu patamar característico com o aparecimento da espécie humana há cerca de 1 ou no máximo de 3 décadas de milhares de anos, no fim do paleolítico, porém a "filogênese" histórica na qual a nossa espécie se aventurou a partir desse momento sofreu profundas transformações. Há uma brutal diferença de escala temporal entre a filogênese biológica e a "filogênese" histórica. ${ }^{26}$

No plano da história, seus agenciamentos receberam inúmeras inovações e ocorreram diversas alterações históricas cumulativas e adaptativas nesse período. Passou-se do fogo para a panela, da pedra lascada à polida e aos metais,

\footnotetext{
${ }^{26}$ São milhões de anos em comparação com milhares de anos. Ver Tomasello (2003: 282-292), e também uma síntese dessa filogenia em André Leroi-Gourhan (2001: 11-14).
}

R. Inter. Interdisc. INTERthesis, Florianópolis, v.6, n.1, p. 15-47, jan./jul. 2009 
estabeleceu-se a agricultura e a pecuária - em suma, houve um devir que acumulou/descartou as agências nas quais o primitivo se envolveu. Trata-se da história da humanidade como história das agências. São transformações ocorridas no plano histórico e não no biológico. Nesse intervalo, de algumas décadas de milhares de anos, permanecemos sustentados por uma mesma e inalterada estrutura biológica, mas do ponto de vista histórico é um alentado conjunto de mudanças. Há uma sucessão de novas agências que se fixaram e se desenvolveram. Por isso falamos abusivamente de uma "filogênese histórica". Há uma constituição na história, as agências são constitutivas desse continuamente "novo" ser, histórico. Se há um motor, este se encontra nas transformações sucessivas dos agenciamentos envolvidos. Isto fundamenta bem a hipótese de Karen Barad, a agência é intra-ativa. A agência produz novas entidades, o humano é e não é o mesmo. Do ponto de vista biológico, nada mudou, porém no cenário histórico, a distância que separa as "formas de vida" dos indivíduos - desde o paleolítico - é brutal. O conjunto histórico de agências acumuladas em dezenas de milhares de anos culminou produzindo o homem iluminista, crédulo de que nascera pleno de racionalidade, desconhecendo esse devir de agenciamentos. Desconhecendo a integração ecológica do humano, o racionalismo inventou o indivíduo solitário, o homem que pensaria sozinho, que estaria só.

\section{OBSTÁCULOS À COMPREENSÃO DA AGÊNCIA E DO PÓS-SOCIAL}

Isso já introduz uma crítica ao esquema racionalista explicativo para o conhecimento, um esquema que violenta a história e a ecologia. O racionalismo, ao considerar a cognição como produto de mentes privilegiadas, isoladas do mundo material que as rodeia, elabora várias fantasmagorias. Desde a ruptura entre o mental e o corpóreo, entre o sensível e o inteligível, entre aparência e essência, ele desenha um "mundo" ficcional de protótipos que reapresentam o mundo real em uma ordem pré-estabelecida. São cópias ou simulacros que pretendem representar a lógica do mundo, representações. Aqui se tem o conhecimento como representação.

Para o racionalismo iluminista seria demasiado modesto supor que a cognição decorreria de uma interação - muito ao estilo de uma seleção natural - das 
práticas existenciais "primitivas" de seres comuns lutando por suas sobrevivências. Tinha que ser grandiloquente, e criou o homem-deus após a Revolução Científica. Assim batizou a si próprio como Homo sapiens. Dotado de grande sabedoria, Homo sapiens sapiens. E apontou um clímax: a Ciência Moderna. Elaborou o corte epistemológico definitivo entre um passado cinzento, uma sonolência na penumbra, e o futuro iluminado, em um despertar eufórico e revolucionário. Agora, com a Ciência, descobria-se a Verdade sob o manto das aparências. O mundo como "representação verdadeira" do Real.

A lenta conquista de agenciamentos - de milenares agenciamentos cumulativos selecionados pela rotina de vida em sociedade - fora apagada. A longa história humana de práticas interativas - ou, intra-ativas - é substituída por um entusiasmo juvenil de pós-renascentistas, uma ego trip. Ora, essa percepção egocêntrica nada mais é do que um simples evento na história e pode ser compreendido historicamente. Um evento egóico que reduziu o processo cognitivo estabelecido no longo devir histórico a uma mera ação de mentes brilhantes, entre homens-livre-pensadores ufanistas de si próprios e de sua racionalidade. $O$ ambiente, a natureza, tornou-se meramente um coadjuvante externo, a ser explicado. O que contava agora eram os juízos sintéticos e analíticos das mentes humanas entre si. Mentes sem corpo, sem matéria, capazes de por pura reflexão desvendarem a lógica subjacente do mundo. Um acordo - racional - entre os homens decidia como o mundo devia ser.

Nessa cavalgada racionalista pouco restou de criativo para a linguagem, que se constituiu como parte periférica deste cenário copista arquitetado por mentes excepcionais sob o crivo da Razão. A linguagem como simples transmissora de idéias racionais que já se constituíam como pensamentos nas subjetividades, pensamentos que se pensam em si mesmos, em abstrações solipsistas.

Sua principal função agenciadora - de ser o agente interativo na produção dinâmica das significações partilhadas - é mascarada e suprimida. Nesse olhar, a linguagem torna-se um corolário estático do conhecimento que ela própria produziu e deu movimento. Ora, mas uma agência somente se efetiva como tal ao ganhar um sentido que emerge da cena, das significações que se fazem na interatividade dos agentes através da instância simbólica. As significações de uma agência desenham na temporalidade aquilo que é o constitutivo intrínseco do que se designa como 
linguagem. Isto é, linguagem como esteio fundamental do devir histórico através de seus agenciamentos.

Dessa forma, é inclusive possível que se construa uma outra compreensão a de representações ideais - que apague os rastos dessa trama de agências em que se configurou a vida e se redesenhe um mundo recheado por fatos, mágicos ou trágicos. A história das agências é omitida e retorna-se a uma história dos acontecimentos, dos fatos.

Com os rastos históricos do agenciamento apagados pode-se elaborar uma idéia de que tudo ocorreu por pura introspecção cerebral. Mas, as representações emergem a partir do entendimento que se tem devido ao resultado operacional das agências, são uma consequência das agências. E não o contrário. Antes das representações orientarem o agir humano, ocorreram agenciamentos que alimentaram essas intelecções, que as fundamentaram e serviram de guia para as ações futuras. As representações decorrem dessa consciência que percebe e extrai somente os resultados e assim sintetiza aquele agenciamento invertendo sua lógica, transfigura a agência em um ato executado exclusivamente pelo indivíduo humano, um ato solitário e mental. Assim, especialmente desde a Revolução Científica, somos dominados pela noção equivocada de que ciência seria um conhecimento produzido pelas mentes excepcionais de indivíduos que brilharam a partir do Renascimento e se tornaram os pais fundadores da Era Moderna.

De uma história do mundo como história das agências passou-se a uma história dos grandes homens e das idéias revolucionárias. Omitem-se os agenciamentos enquanto interatividade mente-corpo, homem-natureza. Entramos no Império das representações.

Nesta cena, trabalho manual e reflexão intelectual se separam, o agenciamento se dilui e desaparece do horizonte compreensivo. Engendramos uma maneira distorcida de apreender a realidade histórica, de perceber as maneiras pelas quais as agências atuam e nas quais os homens tomariam consciência - pela visibilidade dos passos da agência - da relação entre o mundo material e o mundo das idéias. Capturamos tão somente os resultados inteligíveis dos agenciamentos que ficaram ocultos. As concepções de mundo que aí e assim afloram na consciência são representações sobre representações. Representações que os homens fazem sobre suas vidas, sobre a realidade. Nesse ideário pósRenascentista de euforia com o Cogito pré-lluminista, somente ocorrem R. Inter. Interdisc. INTERthesis, Florianópolis, v.6, n.1, p. 15-47, jan./jul. 2009 
representações condicionadas pela forma como as relações sociais e suas existências aparecem nessa experiência distorcida do cotidiano. O humano se transforma no único ator, no senhor racionalista, e a natureza objetiva perde seu animismo medieval, a sua "ecologia" - um resquício fantástico do que se poderia perceber do trabalho da agência material em sua interatividade. Na modernidade, a Natureza se transforma em Livro, pronto para ser lido, representado.

Aliada a esse modo limitado de entendimento sobre a ação humana está a compreensão de linguagem que já veio se delineando desde a antiguidade. É bastante plausível supor que a idéia que então se possuía sobre a linguagem já continha os ingredientes que gestaram esse modelo "representacional" para o homem como o ser racional. Um ser pleno em sua quase-divindade. Uma mente platônico-aristotélica que pensa pensamentos e, em seguida, os verbaliza. A linguagem como simples verbalização transmissora, como exteriorização de uma Idéia interior e anterior. Essa noção irá se desdobrar no século XX na suposição de linguagem como simples instrumento de comunicação societária, de transporte das idéias de indivíduos para outros indivíduos, tal como se difunde nas teorias da comunicação e nos compêndios de linguística.

Afinal, como reforço dessa noção, desde a lenda bíblica, o Verbo se apresentava como o toque divino no impuro indivíduo terrestre. No primórdio dos tempos, o Verbo se fez em homem. Nessa lenda, nada havia para uma etnografia desvendar na história das agências que produziu o humano interativamente com o mundo. Não havia uma história das agências. Não havia ecologia. Tudo começara com o Verbo, uma iluminação dada pela linguagem e que orientava o agir humano. ${ }^{27}$ A linguagem deixa de ser uma aquisição histórica da agência de indivíduos interconectados. Não se via a linguagem como o laço social. Nem havia também um humano como ser histórico, ele já nascera completo, falando como homem-deus cópia do Todo Poderoso que lhe soprou o Verbo nas narinas.

Assim a Retórica e a Oratória esqueciam seu passado constitutivo, sua origem gaguejante - sem gramática e sem escrita - desde o paleolítico. Omitia-se

\footnotetext{
${ }^{27} \mathrm{Na}$ universidade medieval o ensino das sete artes liberais era dividido em duas partes, começava pelo trivium - que constava de três disciplinas: gramática, retórica e lógica - e era seguido pelo quadrivium (aritmética, geometria, astronomia e música). Nesse quadro pedagógico já se encontra uma notável ênfase nas questões de linguagem como uma atividade estritamente cerebral. Nenhuma indicação de que as disciplinas do trivium decorriam de uma etnografia das ações humanas no mundo. Gramática, retórica e lógica consideradas como alicerce para o raciocínio, para o correto dizer-pensar, cujos fundamentos decorriam de qualidades intrínsecas do ser.
}

R. Inter. Interdisc. INTERthesis, Florianópolis, v.6, n.1, p. 15-47, jan./jul. 2009 
que a linguagem se fez através e por seres não-alfabetizados. A linguagem começou analfabética extraindo as sintaxes das cadeias operatórias descritas por Leroi-Gourhan. A linguagem se fez ao obedecer a essas sintaxes estabelecidas nas agências - que vieram a instituir as incipientes gramáticas através do seu uso cotidiano - e ao apreender o léxico com as significações compartilhadas. Isso nos autoriza a colocar uma questão inquietante: quanto que as regras do correto dizerpensar - e até mesmo da lógica humana - devem ao evolver dos eventos no mundo, do mundo? Eventos dos quais partilhamos.

Sim, parece-me bastante plausível, a linguagem e mesmo a lógica como questões etnográficas. A linguagem, nessa pedagogia traçada pela agência, habilitou-se a agenciar coisas e humanos explicitando e conduzindo a maneira do como-seguir-uma-regra wittgensteiniana para a ação interativa nos grupos sociais. $A$ linguagem forjava o Gestaltsehen e constituía as aspirações e rotinas humanas que - por sua vez - definiam as formas de vida, tal como dito por Wittgenstein.

Para cada indivíduo interagir com o meio e convocar outro indivíduo para este agir coletivo sobre a natureza necessitava da linguagem como performance. O trabalho demanda a linguagem. Ou seja, havia a necessidade de explicitar as regras a serem seguidas, de compreender as sintaxes operatórias para a confecção e uso de algum artefato, uma ferramenta ou utensílio partilhado pelo grupo. Assim se dava em cada trabalho de transformação de algo natural, na sobrevivência coletiva diária ante o desafio de um viver em "estado de natureza". Seja na caça, pesca ou mesmo na simples coleta: a linguagem se fazia presente como ferramenta de ação, como trabalho.

A linguagem estimulava a vida, delimitava as "formas de vida", constituía o primitivo como humano, para além de sua filogenia biológica. Inaugurava o devir histórico ao insistir e persistir como herança simbólico-material em cada grupamento societário, forjando as culturas. As formas de viver e existir estavam articuladas simbólico-materialmente com a natureza através das agências constituintes daquela base cultural. Homem-natureza era um binômio integrado, consolidado.

Esta é a maneira sintética pela qual arqueólogos e paleontólogos compreendem a cultura e a existência dos hominídeos ancestrais. Ante um vestígio fóssil - seja de um fragmento de cerâmica ou de uma mandíbula -, o paleontólogo detecta uma integração cultural. Cerâmica e mandíbula são personagens de uma mesma cena histórica, pertencem ao mesmo mundo de agenciamentos. Natureza e 
sociedade reunidas em uma unidade compreensiva. A cerâmica e a mandíbula são personagens que estão integrados através das significações compartilhadas que foram estabelecidas à época em que esses vestígios afloravam à vida. São significações correntes naquela cultura e que cabem ao investigador desvendar, estabelecer o sentido que possuíam nas agências de então.

Para um antropólogo, o objeto material, a cerâmica, fala tanto da estrutura biológica humana arcaica como as partes de um esqueleto falam de costumes e hábitos, estão interligados. Ambos são peças do mesmo quebra-cabeça: uma sócionatureza. O paleontólogo somente vê agências, agências que integram o natural e o social. Ele descreve a história das agências ao perseguir as pistas da passagem humana do paleolítico ao neolítico. Toma como documento dessas agências qualquer registro de uma época primitiva. São registros que mostram o papel implícito desses vestígios na estrutura agenciadora daquele grupo societário. Já as inscrições rupestres expõem explicitamente 0 estágio das significações compartilhadas nas agências e indicam formas de expressão linguística que designam cenas de agenciamento vivenciadas. A linguagem nunca é um mero discurso etéreo, descolado do mundo material.

Essas são percepções triviais para antropólogos e paleontólogos. Entretanto, como é possível que - para nossas sociedades modernas e pós-modernas - tudo isso tenha se perdido? Ou melhor, qual a razão que impede que não se apliquem esses instrumentos potentes de análise para as nossas sociedades? Elas não são um objeto adequado para a investigação antropológica? Ora, a lógica histórica é a mesma, persiste.

Mas algo se perdeu ou permanece invisível, não olhamos para nós mesmos tal como olhamos para o Outro distante, especialmente se ele for um primitivo. Nossa imagem se apresenta através de um gesto mágico, como se fossemos quase divindades que não mais se apequenam interagindo vitalmente com as coisas materiais - agora somos racionais, nossas mentes estão separadas dos corpos. Desde o fim do animismo medieval, o logocentrismo se estabilizou e venceu. Do mundo, somente fazemos representações mentais, objetivas, assépticas e explicativas. Nossa animalidade ficou para trás. A natureza se separou da sociedade e da história.

Entretanto, ouso, aqui está um texto na contramão desse império do Cogito, um texto que proclama por nosso pertencimento ao mundo. Nunca estamos sós. 
Somos seres do mundo, no mundo. Essa perspectiva rompe com o ideário logocêntrico e irrompe na cena histórica como sua matriz constitutiva. A lógica - de agências que fundem a instância simbólica com a material - persiste, natureza e sociedade misturam-se. Nessa sócio-natureza a linguagem é ação, é integração ecológica. Assim constituiu-se o homem como animal histórico. 


\section{REFERÊNCIAS}

AHEARN, Laura M. “Language and agency”. Annual Review of Anthropology. 30, 2001. p. 109-37.

BARAD, Karen. "Agential realism: feminist interventions in understanding scientific practices" in Mario Biagioli (ed.). The science studies reader. New York: Routledge. 1999. p. 1-11.

BARAD, Karen. "Re(con)figuring space, time, and matter" in Marianne Dekoven (ed.). Feminist locations; global and local, theory and practice. New Brunswick.

Rutgers. 2001. p.75-109.

BARAD, Karen. "Posthumanist Performativity: Toward an Understanding of How Matter Comes to Matter". Signs: Journal of Women in Culture and Society. vol. 28. n. 3. 2003. p. 801-831.

BARAD, Karen. Meeting the universe halfway. Durham \& London. Duke University Press. 2007.

CETINA, Karin Knorr and BRUEGGER, Urs. "The Market as an Object of Attachment: Exploring Postsocial Relations in Financial Markets". Canadian Journal of Sociology. 25. 2. 2000. p. 141-168.

CETINA, Karin Knorr. "Sociality with Objects: Social Relations in Postsocial Knowledge Societies”. Theory Culture Society. vol 14 (4). 1997. 1-30.

DERRIDA, Jacques. Gramatologia. São Paulo: Perspectiva, 1999.

ENGELS, Friedrich. "Discurso ante la tumba de Marx." in Marx y Engels: obras escogidas, vol. III. Moscú: Editorial Progreso. 1974.

FLECK, Ludwik. The Genesis and Development of a Scientific Fact. Chicago: University of Chicago Press, 1979.

GIBSON, Kathleen Rita and INGOLD, Tim. (eds.). Tools, language, and cognition in human evolution. Cambridge: Cambridge University Press. 1993.

GIDDENS, Anthony. Central Problems in Social Theory: Action, Structure and Contradiction in Social Analysis. Berkeley and Los Angeles: University of California Press. 1979.

HEWES, Gordon W. A history of speculation on the relation between tools and language In: GIBSON, Kathleen Rita and INGOLD, Tim. 1993. 20-31.

HYPPOLITE, Jean. Gênese e estrutura da Fenomenologia do espírito de Hegel. São Paulo: Discurso Editorial, 1999. 
INGOLD, Tim. "Humanidade e Animalidade". Revista Brasileira de Ciências Sociais. No. 28. ano 10. junho de 1999. 39-53.

KOJĖVE, Alexandre. Introdução à leitura de Hegel. Rio de Janeiro: Contraponto, 2002.

LASH, Scott. "Technological Forms of Life". Theory, Culture \& Society. Vol. 18(1). 2001. 105-120.

LEROI-GOURHAN, André. O gesto e a palavra. Técnica e linguagem. Lisboa: Edições 70, 1990.

LEROI-GOURHAN, André. Os caçadores da pré-história. Lisboa: Edições 70. 2001.

LOCK, Andrew and PETERS, Charles R. (Eds.). Handbook of Human Symbolic Evolution. Oxford: Claredon Press. 1996.

MAIA, Carlos A. "A materialidade da linguagem na história e na ciência" in Linguística Textual, Pragmática etc. Cadernos do CNLF. Rio de Janeiro: Círculo Fluminense de Estudos Filológicos e Lingüísticos. v. X. nº. 13. 2006. 45-56.

MAIA, Carlos A. "Diferença, traço e inscrição: Derrida e a escritura cognitiva do mundo" in Análise do Discurso. Cadernos do CNFL. Rio de Janeiro: Círculo Fluminense de Estudos Filológicos e Lingüísticos. vol XI. n. 07. 2008. 144-151.

MARX, Karl. O capital: crítica de economia política. 3. ed. São Paulo: Nova Cultural. 1988. (Os economistas)

MARX, Karl. Contribución a la crítica de la economia política. México: Siglo XXI editores. 1990.

MARX, Karl. O Capital. Rio de Janeiro: Civilização Brasileira, 2002, Vol I.

MERLEAU-PONTY, Maurice. Fenomenologia da percepção. São Paulo: Martins Fontes. 2006.

STEPHENSON, Peter $\mathrm{H}$. "The significance of silence: On the dialectical evolution of human communication" in Dialectical Anthropology Volume 5, Number 1 / March, 1980. 47-55.

TOMASELLO, Michael. Origens culturais da aquisição do conhecimento humano. São Paulo: Martins Fontes. 2003.

WITTGENSTEIN, Ludwig. Investigações filosóficas. Petrópolis: Vozes. 1994.

Dossiê:

Recebido em: 29/04/2009

Aceito em: 28/06/2009

R. Inter. Interdisc. INTERthesis, Florianópolis, v.6, n.1, p. 15-47, jan./jul. 2009 